\title{
Hedonik Açlık ve Yeme Davranışı İlişkisinin Farklı Beden Kütlelerine Yansıması
}

\author{
Reflection of the Relationship Between Hedonic Hunger and Eating Behavior on Different Body \\ Masses
}

\section{Feride Ayyıldız ${ }^{1}$ İzzet Ülker², Hilal Yıldıran ${ }^{3}$}

Geliş tarihi/Received: 08.04.2021 • Kabul tarihi/Accepted: 06.07.2021

\section{ÖZET}

Amaç: Bu çalışmada, faklı beden kütle indeksi (BKI) değerlerine sahip yetişkin bireylerin hedonik açlık durumlarının ve yeme davranışının değerlendirilmesi amaçlanmıştır.

Bireyler ve Yöntem: Çalışmaya yaşları 19-64 yıl arasında değişen, 541 erkek (\%42.4) ve 735 kadın (\%57.6) olmak üzere toplam 1276 yetişkin birey dahil edilmiştir. Çalışma anketi online olarak (sosyal medya veya e-mail) katılımcılara iletilmiştir. Uygulanan anket formu ile bireylerin bazı demografik özellikleri, beslenme alışkanlıkları, vücut ağırlığı ve boy uzunluğu sorgulanmıştır. Hedonik açlığın değerlendirmesinde Besin Gücü Ölçeği-Tr (BGÖ-Tr), yeme davranışının değerlendirilmesinde Hollanda Yeme Davranışı Anketi ölçekleri kullanılmıştır. Bireyler BKİ sınıflamasına göre üç ayrı gruba ayrılarak değerlendirilmiştir.

Bulgular: Bireylerin \%57.9’u normal vücut ağırlığına sahipken, \%31.2’si fazla kilolu ve \%10.9'u obez sınıflamasında yer almaktadır. Çalışma sonunda BGÖ-Tr toplam puanının obez grupta normal gruba göre daha yüksek olduğu saptanmıştır $(\mathrm{p}<0.05)$. Hollanda Yeme Davranışı Anketi alt grubundan olan kısıtlayıcı yeme ve duygusal yeme puanının fazla kilolu ve obez bireylerde normal vücut ağırlığına sahip olanlara göre daha yüksek olduğu bulunmuştur (p<0.001). BKİ ile besine ulaşılabilirlik, besin mevcudiyeti, BGÖ-Tr toplam puan, kısıtlayıcı yeme ve duygusal yeme alt grupları arasında anlamlı pozitif korelasyon olduğu bulunmuştur ( $\mathrm{p}<0.05)$. Bu çalışmada hedonik açlık değerlendirilmesinde kullanılan BGÖ-Tr toplam ve alt skorlarının DEBQ alt ölçeklerinden duygusal yeme ve dışsal yeme ile pozitif ilişkisi olduğu görülmüştür (p<0.001).

Sonuç: Çalışmadan elde edilen sonuçlara göre hedonik açlık ile yeme davranış bozuklukları arasında ilişki olduğu ve obez bireylerin hedonik açlık ve yeme davranış bozuklukları açısından normal vücut ağırlığına sahip bireylere göre daha riskli olduğu görülmüştür.

Anahtar kelimeler: Hedonik açlık, yeme davranışl, obezite, beden kütle indeksi

\section{ABSTRACT}

Aim: In this study, it was aimed to evaluate the hedonic hunger status and eating behavior of adults with different body mass index (BMI) values.

1. Gazi Üniversitesi, Sağlık Bilimleri Fakültesi, Beslenme ve Diyetetik Bölümü, Ankara, Türkiye • (ㄴ) https://orcid.org/0000-0003-2828-3850

2. İletişim/Correspondence: Erzurum Teknik Üniversitesi, Sağlık Bilimleri Fakültesi, Beslenme ve Diyetetik Bölümü, Erzurum, Türkiye

E-posta: izzetulker@gmail.com • (1) https://orcid.org/0000-0001-9444-5243
3. Gazi Üniversitesi, Sağlık Bilimleri Fakültesi, Beslenme ve Diyetetik Bölümü, Ankara, Türkiye • (i) https://orcid.org/0000-0001-7956-5087 
Subjects and Method: Adults (n: 1276) aged between 19-64 years were included in the study. The study questionnaire was delivered to the participants online (social media or e-mail). Some demographic characteristics, dietary habits, body weight and height were questioned with online form. Food Power Scale-Tr (PFS-Tr) was used to evaluate hedonic hunger and Dutch Eating Behavior Questionnaire (DEBQ) was used to evaluate eating behavior. Individuals were divided into three groups according to BMI classification.

Results: Out of total, $57.9 \%$ of the individuals had normal weight, $31.2 \%$ of them were in the overweight and $10.9 \%$ were in the obese classification. At the end of the study, it was found that total PFS-Tr score was higher in obese group than normal group ( $\mathrm{p}<0.05$ ). The scores of restrictive eating and emotional eating from subgroup of the DEBQ were found to be higher in overweight and obese individuals than those with normal body weight $(\mathrm{p}<0.001)$. A significant positive correlation was found between BMI and food present, food availability, PFS-Tr total score, restrictive eating and emotional eating subgroups $(p<0.05)$. It was found that total and sub-scores of PFS-Tr used in the evaluation of hedonic hunger had a positive relationship with emotional eating and external eating, which are the sub-scales of the DEBQ $(p<0.001)$.

Conclusion: According to the results, it was observed that there was relationship between hedonic hunger and eating behavior disorders, and obese individuals were more at risk in terms of hedonic hunger and eating behavior disorders than individuals with normal body weight.

Keywords: Hedonic hunger, eating behavior, obesity, body mass index

\section{Giriş}

Besin tüketimi bağırsak ile merkezi sinir sistemi (MSS) arasındaki sinirsel ve hormonal sinyaller aracılığı ile kontrol edilmektedir. Yağ dokusu besin tüketiminin kontrolünde etkili sitokinlerin salınımından, beyin ise bu sitokinlerin ve hormonların kandaki düzeyine göre besin tüketimini arttırmak veya azaltmaktan sorumludur. Besin tüketimi ile birlikte açlıkla ilgili sitokinlerin kandaki seviyesi azalırken, tokluk hormonları ile uyarılan sitokinlerin artışı tokluk hissini oluşturur ve besin tüketimi sonlanır (1). Besin tüketiminin bu fizyolojik süreçlerle kontrolü homeostatik açlık olarak tanımlanmaktadır (2). Ancak açlık durumu olmadığı zamanlarda da yemek yeme isteği ve eylemi oluşabilmektedir. Homeostatik geri bildirim mekanizmasının inaktif olduğu bu durumda gerçekleşen besin tüketimi "hedonik açlık" olarak tanımlanmaktadır. Hedonik açlık, metabolik geri bildirim tarafından düzenlenmeyen, bilişsel, ödül ve duygusal faktörlerle ilişkili olan besin tüketimini ifade eder. Beynin kortiko-limbik bölgelerinde bulunan nükleus akümbens, kaudat çekirdeği (beklenti ve motivasyonu yöneten dopaminerjik ödül yolları), amigdala, hipokampus (öğrenme), anterior insula (duyusal işleme), orbitofrontal korteks (ödül değeri değerlendirmesi, yönetici kontrolü ve karar verme) hedonik açlığın anahtar bileşenleridir (3). Homeostatik açlık besin tüketiminden en az 8 saat sonrayı nitelendirmesine rağmen açlık durumunun ölçümü oldukça zordur. Üç Faktörlü Yeme Ölçeği (TFEQ-Tr21), Hollanda Yeme Davranışı Ölçeği (DEBQ) ve Besin Gücü Ölçeği-Tr (BGÖ-Tr) gibi anketler besin tüketimi davranışlarının değerlendirilmesinde kullanılmaktadır. $\mathrm{Bu}$ ölçeklerin içinde BGÖ-Tr bireylerin özellikle hedonik açlık durumunun değerlendirilmesi için Lowe et al. (4) tarafından geliştirilmiş, ülkemizde de geçerlilik güvenilirlik çalışması Ülker ve arkadaşları (5) tarafından yapılmıştır. BGÖ-Tr, yanıtları 5’li likert tip ölçekle alan 13 maddeden oluşan bir öz bildirim anketidir. BGÖ-Tr, farklı besin ortamlarının psikolojik etkisini değerlendirmek için geliştirilmiştir. BGÖ-Tr sadece besin ortamının bir ölçüsü değildir. Aynı zamanda, lezzetli yiyeceklerin bol ve sürekli olarak mevcut olduğu ortamlardaki iştahla ilgili düşünceler, duygular ve isteklerdeki bireysel farklılıkların bir ölçüsüdür. Fizyolojik ihtiyaçların ötesinde, bu yaklaşım, yemek yeme motivasyonundaki bireysel farklılıkların ve lezzetli yiyeceklerin varlığının 
tüketimi daha da artıracağını gösteren bir iştah modeline dayanmaktadır (6). Yapılan çalışmalarda BKI arttıkça BGÖ-Tr skorlarının da arttığı bildirilmektedir (7-9). Yapılan bir çalışmada BKİ'si $25 \mathrm{~kg} / \mathrm{m}^{2}$ den büyük olanların küçük olanlara göre BGÖ-Tr toplam skorlarının anlamlı olarak daha yüksek olduğu bildirilmiştir (7). Benzer şekilde yapılan bir başka çalışmada da BKİ arttıkça BGÖ-Tr toplam skorlarının arttığı belirtilmiştir (9).

Hedonik açlık sonucu lezzetli besinlerin sık sık ve fazla miktarlarda tüketilmesi; yeme bozuklukları, obezite, hipertansiyon, diabetes mellitus, kardiyovasküler hastalıklar, alkole bağlı olmayan karaciğer yağlanması, obstrüktif uyku apnesi ve bazı kanser türleri gibi birçok hastalığa neden olabilmektedir (10). Hedonik açlığın sonuçlarından olan yeme davranış bozuklukları, fiziksel ve ruhsal sağlığı bozan, ölüme neden olabilen, zihinsel bozukluklardır. Son 50 yılda yeme bozuklukları hızla artmaktadır. Vücut ağırlığı, vücut şekli ve yeme tutumları, yeme bozukluklarının kaynağıdır ve sürdürülmesinde anahtar rol oynamaktadır (11). Yeme davranış bozukluklarının değerlendirilmesinde en çok kullanılan ölçeklerden birisi DEBQ ölçeğidir. DEBQ’nun Dişsal Yeme, Duygusal Yeme ve Diyet Kısıtlama alt ölçekleri uyumsuz yeme davranışları (örn., aşırı yeme), daha yüksek BKİ ve negatif duygusal durumlar ile ilişkilendirilmektedir (12). Hedonik açlık ve yeme davranışı bozukluklarının gelişiminde en etkili faktörün ise obezite olduğu bildirilmektedir (13). Literatür incelendiğinde ülkemizde hem hedonik açlık hem de yeme davranışının birlikte değerlendirildiği çalışmaya rastlanılmamıştır. Farklı BKİye sahip bireylerde hedonik açlık ve yeme davranışı arasındaki ilişkinin bireylerin beslenme alışkanlıklarının planlanmasında önemli olabileceği düşünülmektedir. $\mathrm{Bu}$ çalışma ile farklı BKİ değerlerine sahip yetişkin bireylerin hedonik açlık durumlarının ve yeme davranışının değerlendirilmesi amaçlanmıştır.

\section{BİREYLER VE YÖNTEM}

Bu çalışma yaşları 19-64 yıl arasında değişen yetişkin bireyler (n:1276) üzerinde yürütülmüştür. Çalışmaya başlamadan önce örneklemde yer alacak birey sayısını belirlemek amacıyla G*power yazılımı kullanılarak power analizi yapılmıştır. Alfa $(\alpha)=0.05$, güç $(1-\beta)=0.95$ alınarak yapılan analiz sonucunda üç farklı BKI sinıfinın (normal, fazla kilolu ve obez) her birinden en az 138 bireyin olması gerektiği hesaplanmıştır. Bu çalışma için Gazi Üniversitesi Etik Komisyonu'ndan 08.09.2020 tarih ve 08 sayll (91610558-604.01.02) toplantısında etik kurul onayı alınmıştır ve çalışmaya katılan tüm bireylerin onayları online olarak alınıp çalışmaya ait veriler değerlendirilmiştir.

\section{Çalışmanın Dizaynı}

Çalışmada bireylere ait bazı demografik özellikler (yaş, cinsiyet), beslenme alışkanlıkları, vücut ağırlığı (kg) ve boy uzunluğu $(\mathrm{cm})$ online olarak sorgulanmıştır. Uygulanan anket formu sosyal medya veya e-mail yoluyla katılımcılara ulaştırılmıştır. Hedonik açlığın değerlendirmesinde Besin Gücü Ölçeği (BGÖ-Tr) ve yeme davranışının değerlendirilmesinde ise Hollanda Yeme Davranışı Anketi (DEBQ) ölçekleri kullanılmıştır.

\section{Antropometrik Ölçümler}

Çalışmaya katılan bireylerin vücut ağırlığı (kg) ve boy uzunluğu $(\mathrm{cm})$ verileri beyana dayalı alınmıştır. Vücut ağırlığı (kg)/boy uzunluğu $\left(\mathrm{m}^{2}\right)$ denklemiyle BKI değeri hesaplanıp, Dünya Sağlık Örgütü sınıflamasına göre değerlendirilmiştir. Buna göre BKİ 18.5-24.99 $\mathrm{kg} / \mathrm{m}^{2}$ arasinda olanlar normal, 25.0-29.99 kg/m² arasinda olanlar fazla kilolu, $\geq 30 \mathrm{~kg} / \mathrm{m}^{2}$ olanlar obez olarak sınıflandırılmıştır (14).

\section{Besin Gücü Ölçeği (BGÖ-Tr)}

Hedonik açlık durumunun değerlendirilmesinde kullanılan BGÖ-Tr ölçeği Lowe et al. (4) tarafindan geliştirilmiştir. Orijinalölçek 15 sorudan oluşmaktadır. Ölçeğin Türkçe geçerlilik ve güvenirliliği ise Ülker ve arkadaşları (5) tarafindan yapılmıştır. Ölçeğin Türkçe versiyonu 13 sorudan oluşmaktadır. Orijinal ölçekteki 
5 ve 13. maddeler en yüksek hata kovaryansını göstermesi nedeniyle ve ayrıca model-ft indekslerini sağlamak için çıkartılmıştır. Değerlendirilmesi 5'li likert ölçeğine (1: kesinlikle katılmıyorum, 2: katılmıyorum, 3: kararsızım, 4: katılıyorum, 5: kesinlikle katılıyorum) göre yapılmaktadır. Besin Gücü Ölçeği'nin besin bulunabilirliği, besin mevcudiyeti, besinin tadına bakılması olmak üzere 3 alt ölçek değerlendirmesinden ve 13 maddeden oluşmaktadır. Birincisi, besinlerle ilgili genel düşünceleri (1, 2, 9, 10. maddeler) değerlendiren besin bulunabilirliğidir. İkincisi, besin mevcudiyeti alt ölçeği, bireyin doğrudan erişebildiği $(3,4,5$ ve 6. maddeler) yiyeceğe olan çekiciliği değerlendiren maddelerden oluşmaktadır. Üçüncüsü ise besinin tadına bakılması, ilk tadıldığında yiyeceklerden elde edilen arzuyu/zevki değerlendiren (7, 8, 11, 12 ve 13. maddeler) maddeleri içermektedir. Değerlendirme sonunda 3 alt ölçek puanı ve toplam ölçek puanı olmak üzere 4 puan elde edilmektedir. Toplam ve alt ölçek puanları, madde puanlarının toplanması ve madde sayısına bölünmesiyle elde edilmektedir. Puanın artması hedonik açlık durumuna yatkınlığın fazla olduğunu göstermektedir (5).

\section{Hollanda Yeme Davranışı Anketi (DEBQ)}

Çalışmada yeme davranışının değerlendirilmesinde Hollanda Yeme Davranışı Anketi (DEBQ) kullanılmıştır. Gündüz ve ark. (10)'nın Van Strein et al. tarafindan geliştirildiği belirtilen bu ölçeğin Türkçe geçerlilik ve güvenirliliği Bozan ve arkadaşlarınca (15) yapılmıştır. Üç alt ölçekten (kısıtlayıcı yeme, duygusal yeme ve dışsal yeme) oluşan bu anket, 5'li likert ölçeğine (1: hiçbir zaman, 2: nadiren, 3: bazen, 4: sık, 5: çok sık) göre değerlendirilmektedir. Ankette yer alan ilk 10 soru kısıtlayıcı yeme, 11-23. sorular duygusal yeme ve 24.-33. sorular dışsal yeme alt ölçeğinde yer almaktadır. Anketin toplam puanı hesaplanmayı, alt ölçeklerin toplam puanları hesaplanmaktadır. Hesaplamada 31. soru ters soru olarak, dışsal yeme alt ölçeğinde toplam puanı etkilemektedir. Alt ölçeklerin kesim noktası bulunmazken, puanın artması yeme davranışının olumsuzluğuyla ilişkilendirilmektedir (15).

\section{Verilerin İstatistiksel Değerlendirmesi}

Çalışmada elde edilen veriler SPSS 24.0 programı kullanılarak değerlendirilmiştir. Çalışmada tanımlayıcı değerler sayı (n), yüzde (\%), aritmetik ortalama $(\overline{\mathrm{X}})$, standart sapma (SS) olarak belirtilmiştir. İkiden fazla bağımsız değişkenin karşılaştırılmasında One-way ANOVA testi kullanılmıştır. İkili gruplar arasındaki farklılıkların değerlendirilmesinde Tukey testi kullanılmıştır. İki nicel verinin korelasyonun non-parametrik korelasyon kat sayısı olan Spearman kullanılmıştır. Tüm incelemeler \%95 güven düzeyinde istatistiksel olarak yapılmış ve yorumlanmıştır.

\section{BULGULAR}

Çalışmaya \%42.4’ü (n:541) erkek, \%57.6’sı (n:735) kadın olmak üzere toplam 1276 birey dahil edilmiştir. Katılımcıların yaş ortalaması $29.1 \pm 10.24$ yıldır. Katılımcıların BKİ ortalaması kadınlarda $25.5 \pm 3.59 \mathrm{~kg} /$ $\mathrm{m}^{2}$, erkeklerde ise $23.9 \pm 4.37 \mathrm{~kg} / \mathrm{m}^{2}$ dir. Bireylerin BKİ değerlerinegöre vücutağırlıklarının değerlendirilmesi Tablo 1'de verilmiştir. Katılımcıların \%57.9'u normal vücut ağırlığına sahipken, \%31.2'si fazla kilolu ve \%10.9’u obez sinıflamasında yer almaktadır. Erkek bireylerin \%49.4’ü, kadın bireylerin \%64.2'si normal BKİ sinıflamasında yer almaktadır.

Tablo 1. Bireylerin beden kütle indeksi (BKi) değerlerine göre vücut ağırlıklarının değerlendirilmesi

\begin{tabular}{lcccccc}
\hline $\begin{array}{l}\text { BKI sınıflaması } \\
\left(\mathbf{k g} / \mathbf{m}^{\mathbf{2}}\right)\end{array}$ & $\mathbf{S}$ & $\mathbf{\%}$ & $\mathbf{S}$ & $\mathbf{\%}$ & \multicolumn{2}{c}{ Toplam (n:1276) } \\
\hline Normal & 267 & 49.4 & 472 & 64.2 & 739 & $\mathbf{\text { S }}$ \\
Fazla kilolu & 216 & 39.9 & 182 & 24.8 & 398 & 31.2 \\
Obez & 58 & 10.7 & 81 & 11.0 & 139 & 10.9 \\
\hline
\end{tabular}


Tablo 2. Bireylerin hedonik açlık ve yeme davranışlarının BKİ sınıflamasına göre değerlendirilmesi

\begin{tabular}{|c|c|c|c|c|}
\hline $\begin{array}{l}\text { Hedonik Açlık ve } \\
\text { Yeme Davranışı }\end{array}$ & $\begin{array}{c}\text { Normal } \\
\text { (n:739) } \\
\overline{\mathbf{X}} \pm \mathrm{SS}\end{array}$ & $\begin{array}{c}\text { Fazla kilolu } \\
\text { (n:398) } \\
\overline{\mathbf{X}} \pm \text { SS }\end{array}$ & $\begin{array}{c}\text { Obez } \\
\text { (n:139) } \\
\overline{\mathbf{X}} \pm \text { SS }\end{array}$ & $\mathbf{p}$ \\
\hline Besine ulaşılabilirlik & $2.7 \pm 0.98^{\mathrm{a}}$ & $2.8 \pm 0.94^{\mathrm{b}}$ & $3.0 \pm 0.99^{b}$ & 0.001 \\
\hline Besin mevcudiyeti & $3.0 \pm 0.91^{\mathrm{a}}$ & $3.2 \pm 0.87^{\mathrm{b}}$ & $3.3 \pm 0.88^{b}$ & $<0.001$ \\
\hline Besinin tadına bakılması & $3.3 \pm 0.83$ & $3.2 \pm 0.81$ & $3.4 \pm 0.90$ & 0.341 \\
\hline BGÖ-Tr Toplam puan & $3.0 \pm 0.79^{\mathrm{a}}$ & $4.9 \pm 3.13^{\mathrm{a}, \mathrm{c}}$ & $4.9 \pm 3.26^{\mathrm{b}, \mathrm{c}}$ & 0.006 \\
\hline \multicolumn{5}{|l|}{ DEBQ } \\
\hline Kisitlayıcı yeme & $23.8 \pm 8.10^{\mathrm{a}}$ & $25.5 \pm 7.27^{b}$ & $25.9 \pm 8.10^{\mathrm{b}}$ & $<0.001$ \\
\hline Duygusal yeme & $28.8 \pm 12.30^{\mathrm{a}}$ & $31.4 \pm 12.21^{b}$ & $32.4 \pm 13.26^{\mathrm{b}}$ & $<0.001$ \\
\hline Dişsal Yeme & $30.3 \pm 5.90$ & $31.0 \pm 5.89$ & $30.5 \pm 6.26$ & 0.198 \\
\hline
\end{tabular}

Tablo 2'de bireylerin hedonik açlık ve yeme davranışlarının BKİ sinıflamasına göre değerlendirilmesi gösterilmiştir. BGÖ-Tr toplam puanının, obez grupta normal gruba göre daha yüksek olduğu görülmektedir $(\mathrm{p}<0.05)$. Fazla kilolu ve obez bireylerin normal vücut ağırlığına sahip olanlara göre besine ulaşılabilirlik ve besin mevcudiyeti durumunun daha yüksek olduğu saptanmıştır $(\mathrm{p}<0.05)$. DEBQ alt grubundan olan kisitlayıcı yeme ve duygusal yeme puanının fazla kilolu ve obez bireylerde normal vücut ağırlığına sahip olanlara göre daha yüksek olduğu gösterilmiştir $(\mathrm{p}<0.001)$.

Bireylerin BKİ değerlerine göre hedonik açlık ve yeme davranışının korelasyonu Şekil 1'de verilmiştir. BKİ ile besine ulaşllabilirlik, besin mevcudiyeti, BGÖTr toplam puan, kısitlayıcı yeme ve duygusal yeme alt grupları arasında anlamlı pozitif korelasyon olduğu görülmektedir ( $\mathrm{p}<0.05)$. BKİ ile besinin tadına bakılması ve dışsal yeme alt ölçekleri arasında bir ilişki bulunmamıştır ( $\mathrm{p}>0.05)$.
Bireylerin BGÖ-Tr ve DEBQ alt skorlarının değerlendirilmesi Tablo 3'de verilmiştir. Bu çalışmada hedonik açlık değerlendirilmesinde kullanılan BGÖTr toplam ve alt skorlarının DEBQ alt ölçeklerinden duygusal yeme ve dişsal yeme ile pozitif ilişkisi olduğu görülmüştür $(\mathrm{p}<0.001)$.

\section{TARTIŞMA}

$\mathrm{Bu}$ çalışma farklı BKİye sahip bireylerin hedonik açlık ve yeme davranışını değerlendirmek amacıyla planlanmış ve yürütülmüştür. Çalışmaya katılan bireylerin \%57.9'u normal BKİ değerinde, \%31.2'si fazla kilolu ve \%10.9'u obez sinıflamasinda yer almaktadır (Tablo 1).

Gerek hedonik açlık gerekse yeme davranış bozukluğu artan BKİ ile ilişkilendirilmektedir. Hedonik açlığın değerlendirilmesinde kullanılan güvenilir yöntemlerden birisi BGÖ-Tr anketidir (6). Besin gücü ölçeği skorlarının obez bireylerde obez olmayan bireylere göre daha yüksek olduğu bildirilmektedir.

Tablo 3. Bireylerin BGÖ-Tr ve DEBQ alt skorlarının değerlendirilmesi

\begin{tabular}{|c|c|c|c|c|c|c|}
\hline & \multicolumn{2}{|c|}{ Kısıtlayıcı yeme } & \multicolumn{2}{|c|}{ Duygusal yeme } & \multicolumn{2}{|c|}{ Dişsal Yeme } \\
\hline & $\mathbf{r}$ & $\mathbf{p}$ & $\mathbf{r}$ & $\mathbf{p}$ & $\mathbf{r}$ & $\mathbf{p}$ \\
\hline BGÖ-Tr toplam puan & 0.021 & 0.454 & 0.381 & $<0.001$ & 0.543 & $<0.001$ \\
\hline Besine ulaşılabilirlik & 0.052 & 0.063 & 0.420 & $<0.001$ & 0.455 & $<0.001$ \\
\hline Besin mevcudiyeti & 0.025 & 0.380 & 0.340 & $<0.001$ & 0.477 & $<0.001$ \\
\hline Besinin tadına bakılması & -0.018 & 0.511 & 0.248 & $<0.001$ & 0.493 & $<0.001$ \\
\hline
\end{tabular}



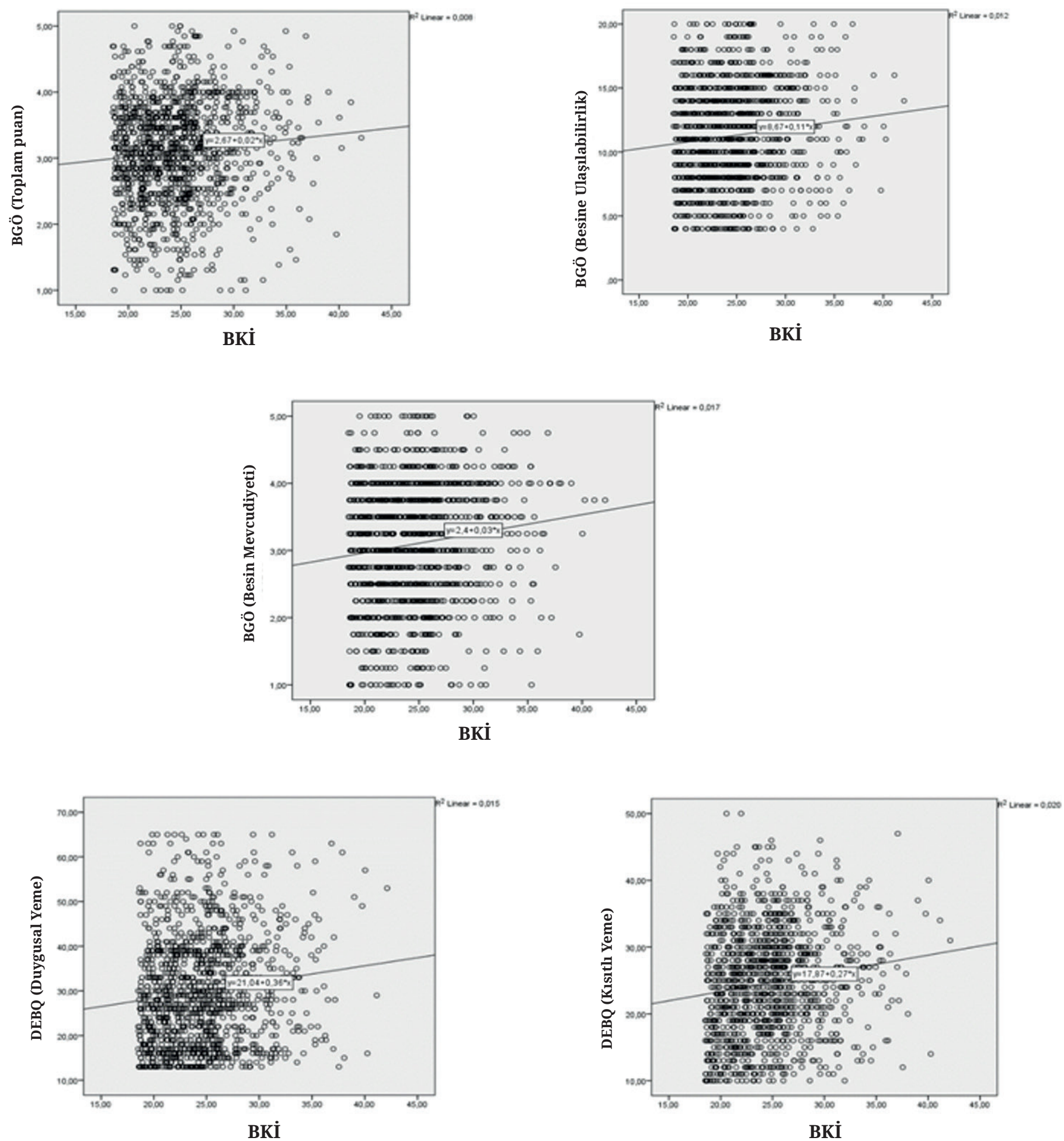

BKİ: Beden Kütle İndeksi, BGÖ-Tr: Besin Gücü Ölçeği-Tr, DEBQ: Hollanda Yeme Davranışı Anketi

Şekil 1. Bireylerin BKİ değerlerine göre hedonik açlık ve yeme davranışının korelasyonu 
Yetişkin obez bireyler ile obez olmayan bireyler arasındaki BGÖ-Tr skorlarını değerlendirmek amaciyla Schultes et. al (16) tarafindan yapllan bir çalışmada, obez bireylerin BGÖ-Tr skorlarının obez olmayan bireylere göre daha yüksek olduğu ve BGÖ-Tr skorları arasında farkın istatiksel olarak anlamlı olduğu bulunmuştur. Benzer şekilde obez bireyler ile obez olmayan bireylerin hedonik açlık durumlarını karşılaştırmak için Thomas et. al (17) tarafından yapılan çalışmada da obez olan bireylerin toplam BGÖ-Tr skoru ile BGÖ-Tr'nin alt skorlarının tamaminın obez bireylerde anlamlı olarak daha yüksek olduğu bulunmuştur. Riberio et. al (18) tarafından yapılan BKİ ile hedonik açlık arasındaki ilişkinin değerlendirildiği başka bir çalışmada da obez olmayan katılımcılar ile obez olanların BGÖ-Tr skorları karşılaştırılmış ve obez katılımcıların toplam BGÖ-Tr skorları obez olmayanlara göre ortalama $1.9 \pm 0.04$ kadar daha yüksek olduğu bulunmuştur. BGÖ-Tr alt ölçek skorlarının da obez bireylerde daha yüksek olduğu bildirilmektedir (18). Obez ve normal vücut ağırlığına sahip bireylerin besin gücü ölçeği toplam skor ve alt ölçek skorları arasındaki farkın istatistiksel olarak anlamlı olduğu bildirilmektedir $(p<0.001)$. Yapılan bu çalışmada da obez bireylerin BGÖ-Tr toplam skorunun zaylf bireylere göre daha yüksek olduğu ( $p=0.006$, Tablo 2) ve BKİ arttıkça BGÖ-Tr toplam skoru ve alt ölçek skorlarının arttığı bulunmuştur (Şekil 1). Aynı zamanda BGÖ-Tr toplam skoru ve alt ölçeklerinden besinin tadına bakılması dışında diğer alt ölçekler ile BKİ arasında pozitif yönde korelasyon bulunmuştur $(p<0.001$, Şekil 1). Benzer şekilde başka bir çalışmada BKİ ile BGÖ-Tr skorları arasında zayıf korelasyon olduğu vurgulanmaktadır (6). Yapılan bu çalışma sonuçlarına dayanarak vücut ağırlığı fazlalığının BGÖ-Tr skorlarındaki artışın sonucu olabileceği düşünülmektedir.

Yeme davranış bozuklukları günümüzde giderek artmaktadır. Artan yeme davranış bozuklukları beraberinde birçok kronik hastalığı getirmektedir. Yeme davranış bozuklukları ile ortaya çıkan hastalıkların başında obezite yer almaktadır (19). BKİnin artması ile yeme davranış bozukluklarının bir değerlendirmesi olan DEBQ skorlarının da artacağı bildirilmektedir (20). Snoek et. al (21) tarafindan yapılan çalışmada da dışsal yeme, kısıtlayıcı yeme, duygusal yeme ve DEBQ toplam skorunun obez bireylerde normal vücut ağırlığına sahip bireylere göre daha yüksek olduğu bulunmuştur. Yapılan bu çalışmada da DEBQ alt grubundan olan kısıtlayıcı yeme ve duygusal yeme puanının fazla kilolu ve obez bireylerde normal vücut ağırlığına sahip olanlara göre daha yüksek olduğu gösterilmiştir ( $p<0.001$, Tablo 2). Ayrıca DEBQ ölçeğinin alt ölçekleri olan duygusal yeme ve kısıtlayıcı yeme alt ölçek skorlarının BKİ ile pozitif yönde arttığı ve bu durumun da istatistiksel olarak anlamlı olduğu görülmüştür $(p<0.001$, Şekil 1). Literatürde DEBQ ile BKİ arasındaki ilişkiyi değerlendiren çalışma sınırlıdır. Yapılan bir çalışmada üniversite öğrencilerinin yeme davranışları ile BKI arasındaki ilişki değerlendirilmiş ve BKI arttıkça DEBQ skorlarının da arttığı bildirilmektedir (22). Benzer şekilde Lluch et. al (23) tarafindan yapılan çalışmada da yukarıda bahsedilen iki çalışma gibi her iki cinsiyette de DEBQ toplam skorunun ve alt ölçek skorlarının obezlerde daha yüksek olduğu bildirilmektedir. Buna göre obez bireylerde yeme davranış bozukluklarının diğer sınıflamalara göre daha fazla olduğu söylenebilir.

Hedonik açlık durumunun varlığı yeme davranışı bozuklukları ile ilişkili olacağı düşünülmektedir (24). Özellikle hedonik açlık arttıkça tıkanırcasına yeme sendromu gibi yeme davranışı bozukluklarının gelişebileceği ve obeziteyle sonuçlanabileceği bildirilmektedir (25). Bu çalışmada hedonik açlık değerlendirilmesinde kullanılan BGÖ-Tr toplam ve alt skorlarının DEBQ alt ölçeklerinden duygusal yeme ve dışsal yeme ile pozitif ilişkisi olduğu görülmüştür ( $p<0.001$, Tablo 3). Ancak literatürde hedonik açlıkla yeme davranış bozukluğu arasındaki ilişkiyi değerlendiren çalışmalar sınırlı olsa da BGÖ-Tr skorlarının yeme bozukluğu semptomları açısından prognostik öneminin olabileceği düşünülmektedir (26). 
Sonuç olarak bu çalışmadan elde edilen sonuçlara göre hedonik açlık ile yeme davranış bozuklukları arasında ilişki olduğu ve obez bireylerin hedonik açlık ve yeme davranış bozuklukları açısından normal vücut ağırlığına sahip bireylere göre daha riskli olduğu görülmüştür. Yeme davranışı bozukluğu şüphesi olan obez bireylerde BGÖ-Tr’nin kullanarak besin tüketimi ile ilgili hedonik faktörlerin değerlendirilmesinin semptomlar gelişmeden önlem alınması açısından önemli olduğu ve tedavi stratejilerinin belirlenmesinde önemli olabileceği düşünülmektedir.

Yazarlık katkısı - Author contributions: Çalışma tasarımı, makale yazımı ve onayı: HY; Çalışma verilerinin elde edilmesi, verilerin analiz edilmesi, makale yazımı: FA, İÜ - Study design, article writing and approval: HY; Obtaining study data, analyzing data, writing article: $F A, \dot{I} \ddot{U}$.

Etik Kurul Onayı - Ethics approval: Gazi Üniversitesi Etik Komisyonundan onay alınmıştır (Karar Tarihi: 08.09.2020 Karar No: 08-91610558-604.01.02).

Çıkar çatışması - Conflict of interest: Yazarlar çıkar çatışması olmadığını beyan ederler. - The authors declare that they have no conflict of interest.

\section{KAYNAKLAR}

1. Simpson KA, Bloom SR. Appetite and hedonism: Gut hormones and the brain. Endocrinol Metab Clin North Am. 2010;39(4):729-14.

2. Sumithran P, Prendergast LA, Delbridge E, Purcell K, Shulkes A, Kriketos A, et al. Long-term persistence of hormonal adaptations to weight loss. N Engl J Med. 2011;365(17):1597-7.

3. Berthoud HR. Metabolic and hedonic drives in the neural control of appetite: Who is the boss?. Curr Opin Neurobiol. 2011;21(6):888-8.

4. Lowe MR, Butryn ML, Didie ER, Annunziato RA, Thomas JG, Crerand CE, et al. The Power of Food Scale. A new measure of the psychological influence of the food environment. Appetite. 2009;53(1):114-8.

5. Ulker I, F, Yildiran H. Validation of the Turkish version of the Power of Food Scale in adult population. Eat Weight Disord. 2020;26(4): 1179-1186.

6. Cappelleri JC, Bushmakin AG, Gerber RA, Leidy NK, Sexton CC, Karlsson J, et al. Evaluating the Power of Food Scale in obese subjects and a general sample of individuals: Development and measurement properties. Int J Obesity. 2009;33(8):913-9.

7. Chmurzynska A, Mlodzik-Czyzewska MA, Radziejewska A, Wiebe DJ. Hedonic hunger is associated with intake of certain high-fat food types and BMI in 20-to 40-year-old adults. Nutr J. 2021;151(4):820-5.

8. Aliasghari F, Yaghin NL, Mahdavi R. Relationship between hedonic hunger and serum levels of insulin, leptin and BDNF in the Iranian population. Physiol Behav. 2019;199:84-7.

9. Ely AV, Howard J, Lowe MR. Delayed discounting and hedonic hunger in the prediction of lab-based eating behavior. Eat Behav. 2015;19:72-5.

10. Gündüz N, Aakhilal M, Sevgi EN. Hedonik açlık. Izmir Democracy University Health Sciences Journal.2020;3(1):80-16.

11. Treasure J, Duarte TA, Schmidt U. Eating disorders. Lancet. 2020;395(10227):899-12.

12. Mason TB, Pacanowski CR, Lavender JM, Crosby RD, Wonderlich SA, Engel SG, et al. Evaluating the ecological validity of the Dutch Eating Behavior Questionnaire among obese adults using ecological momentary assessment. Assessment. 2019;26(5):907-7.

13. Berridge KC. 'Liking' and 'wanting' food rewards: Brain substrates and roles in eating disorders. Physiol Behav. 2009;97(5):537-13.

14. Pi-Sunyer, FX. Obesity: criteria and classification. Proceedings of the Nutrition Societ. 2000;59(4): 505-509.

15. Bozan N, Bas M, Asci FH. Psychometric properties of Turkish version of Dutch Eating Behaviour Questionnaire (DEBQ). A preliminary results. Appetite. 2011;56(3):564-6.

16. Schultes B, Ernst B, Wilms B, Thurnheer M, Hallschmid $M$. Hedonic hunger is increased in severely obese patients and is reduced after gastric bypass surgery. Am J Clin.Nutr. 2010;92(2):277-6.

17. Thomas EA, Bechtell JL, Vestal BE, Johnson SL, Bessesen DH, Tregellas JR, et al. Eating-related behaviors and appetite during energy imbalance in obese-prone and obese-resistant individuals. Appetite. 2013;65:96-6.

18. Ribeiro G, Camacho M, Santos O, Pontes C, Torres S, Oliveira-Maia AJ. Association between hedonic hunger and body-mass index versus obesity status. Scientific Reports. 2018;8(1):1-9.

19. Silventoinen K, Konttinen $H$. Obesity and eating behavior from the perspective of twin and genetic research. Neurosci Biobehav Rev. 2020;109:150-15.

20. Zhao AW, McGowan CC, Zenk SN, Kershaw KN. Associations of the consumer food environment with eating behaviors and Body Mass Index. Public Health Nutr. 2020;23(17):3197. 
21. Snoek HM, Van Strien T, Janssens JM, Engels RC. Emotional, external, restrained eating and overweight in Dutch adolescents. Scand J Psychol. 2007;48(1):23-9.

22. Sanlier N, Biyikli AE, Biyikli ET. Evaluating the relationship of eating behaviors of university students with body mass index and self-esteem. Ecol Food Nutr. 2015;54(2):175-10.

23. Lluch A, Herbeth B, Mejean L, Siest G. Dietary intakes, eating style and overweight in the Stanislas Family Study. Int J Obes. 2000;24(11):1493-9.
24. Lowe MR, Arigo D, Butryn ML, Gilbert JR, Sarwer D, Stice E. Hedonic hunger prospectively predicts onset and maintenance of loss of control eating among college women. Health Psychol. 2016;35(3):238.

25. Manasse SM, Espel HM, Forman EM, Ruocco AC, Juarascio AS, Butryn ML, et al. The independent and interacting effects of hedonic hunger and executive function on binge eating. Appetite. 2015;89:16-5.

26. Witt AA, Lowe MR. Hedonic hunger and binge eating among women with eating disorders. Int J Eat Disord. 2014;47(3):273-7. 